Center for Building Technology National Engineering Laboratory National Bureau of Standards Washington, D.C. 20234

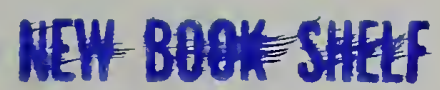

February 1980

Prepared for

Federal Highway Administration

Offices of Research \& Development

Washington, D.C. 20590

$Q C$

100

.456

NO. 80-1974

1980 



\title{
LEAD CHROMATE PIGMENTS - A \\ LITERATURE SURVEY ON \\ ENVIRONMENTAL AND TOXIC \\ EFFECTS
}

\author{
M. A. Post and P. G. Campbell
}

This report is an updated version of the one appearing as Appendix A in Report No. FHWA-RD-78-1 Nontoxic Yellow Traffic Striping.

Center for Building Technology

National Engineering Laboratory

National Bureau of Standards

Washington, D.C. 20234

February 1980

\section{Prepared for}

Federal Highway Administration

Offices of Research and Development

Washington, D.C. 20590

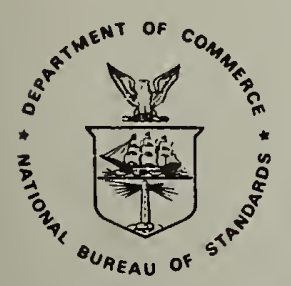

U.S. DEPARTMENT OF COMMERCE, Philip M. Klutznick, Secretary

Luther H. Hodges, Jr., Deputy Secretary

Jordan J. Baruch, Assistant Secretary for Science and Technology

NATIONAL BUREAU OF STANDARDS, Ernest Ambler, Director 



\section{ABSTRACT \\ Lead Chromate Pigments - A Literature Survey on \\ Environmental and Toxic Effects \\ by M. A. Post and P. G. Campbel1}

In connection with an evaluation of the performance of possible alternative yellow pigments, a literature search was made on the toxicity and environmental effects of lead chromate pigments. The literature reveals that workers in chromate plants in the U.S., Europe and Japan have had a high incidence of lung cancer as well as other respiratory ailments. Further, reports on the biologic interactions of chromium show that chromium in its hexavalent state (chromate, dichromate) penetrates body membranes such as skin and the walls of red blood cells and is subsequently reduced to the trivalent state and complexed with organic molecules. While the carcinogen in the chromate manufacturing process has not been identified, animal experiments have shown that calcium chromate can produce cancer in rats. Information is presented on sources of chromium in air and water pollution. Also, the pollution aspects of lead and chromium in storm water runoff and as street surface contaminants are reviewed.

Key words: Air pollution; chromite ore; environmental effects; lead chromate pigments; storm water runoff; toxicity; water pollution. 


\section{Table of Contents}

$\underline{\text { Page }}$

1. InTRODUCTION $\ldots \ldots \ldots \ldots \ldots \ldots \ldots \ldots \ldots \ldots \ldots \ldots \ldots \ldots \ldots \ldots \ldots$

2. MANUFACTURING PROCESS OF CHROMATE PIGMENTS $\ldots \ldots \ldots \ldots .2$

3. EFFECT OF CHROMATES ON WORKERS IN THE MANUFACTURING

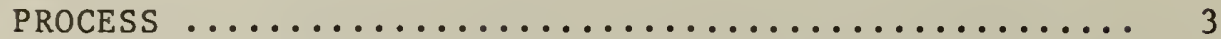

4. EFFECTS OF LEAD-CONTAINING SPRAY-APPLIED PAINTS ON

PAINTERS WORKING IN CONFINED AREAS $\ldots \ldots \ldots \ldots \ldots \ldots . . .9$

5. BIOLOGICAL INTERACTIONS OF CHROMIUM AND CHROMATES .... 14

6. ANIMAL STUdiES WITH HEXAVALENT CHROMIUM $\ldots \ldots \ldots \ldots \ldots . . \ldots$

7. AIR POLLUTION STUdies RELATING TO CHROMIUM ......... 18

8. WATER POLLUTION STUDIES RELATING TO CHROMIUM .IN RUNOFF FROM STREETS .................... 21

9. STREET CONSTRUCTION MATERIALS AND SURFACE CONTAMINANTS AS SOURCES OF CHROMIUM ..................... 25

10. CALCULATION OF POSSIBLE CONTRIBUTION OF YELLOW TRAFFIC STRIPING TO LEAD AND CHROMIUM CONTENT OF ROADWAY

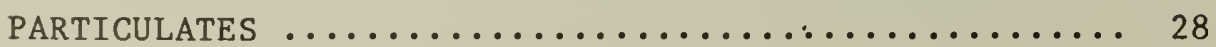

11. CONCLUSIONS ......................... 29

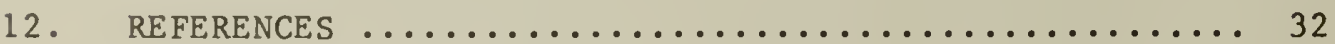




\subsection{INTRODUCTION}

This report is the result of a literature survey carried out in connection with an evaluation of the performance of yellow pigments which might be possible alternatives to lead chromate for use in traffic paints, i.e., paints used for highway striping. In this part of the project, the focus was on the toxicity and environmental effects of lead chromate pigments.

At the present time, lead chromate pigments are the only yellow pigments used in traffic paints. Concern about their use is apparent from the recent warning given by the Dry Color Manufacturer's Association to pigment manufacturers and their customers as to the possible carcinogenic effects of certain chromate pigments [1]*.

A computer search of the Medline, Toxline and Chemical Abstracts data bases was performed. From this search, the bulk of the references was obtained. The NTIS (National Technical Information Service) was also used and EPA (Environmental Protection Agency) reports were searched. In addition, Chemical Titles, World Surface Coatings Abstracts, Journal of $0 i 1$ and Colour Chemists Association, American Paint Journal, Journal of Paint Technology, Paint and Varnish Production, Paint Manufacture, Canadian Paint and Finishing, and Pigment and Resin Technology were consulted.

\subsection{MANUFACTURING PROCESS OF CHROMATE PIGMENTS}

Before discussing the results of a literature search on the effects of chromates on the human body, a description of the manufacturing process for lead chromate is presented.

\footnotetext{
* Numbers in brackets refer to references at the end of this paper.
} 
The principal lead ore is the sulfide. Lead ores are first concentrated by a series of flotation processes to remove the zinc sulfide and the gangue materials. The concentrated ore is then roasted in air to convert most of the sulfide to the oxide. The lead oxide is dissolved in nitric acid to form lead nitrate. The solution must be slightly acld, otherwise hydrolysis occurs and basic nitrates are precipitated. The process is described by Nebergall and Schmidt [2] and the reactions are:

$$
\begin{aligned}
& 2 \mathrm{PbS}+3 \mathrm{O}_{2}+2 \mathrm{PbO}+2 \mathrm{SO}_{2} \\
& \mathrm{PbO}+2 \mathrm{HNO}_{3}-\mathrm{PB}\left(\mathrm{NO}_{3}\right)_{2}+\mathrm{H}_{2} \mathrm{O} \\
& \mathrm{PB}++\mathrm{NO}_{3}^{-}+\mathrm{H}_{2} \mathrm{O}+\mathrm{Pb}(\mathrm{OH}) \mathrm{NO}_{3}+\mathrm{H}^{+}
\end{aligned}
$$

The principal chromium ore is chromite. The chromite is roasted with sodi with or without lime, and the sodium chromate is leached out wtth water [3]. If sodium dischromate is used in the production of lead chromate, this is produced from the solution of sodium chromate by reaction with dilute sulfuric acid. Wormald [4] described the process where solutions of sodium chromate or dichromate are produced in individual tanks. The lead nitrate solution is added and lead chromate is precipitated. The lead chromate pigment is collected in the filter press, washed, dried and milled. The reactions involved are:

$2 \mathrm{Cr}_{2} \mathrm{O}_{3}+4 \mathrm{Na}_{2} \mathrm{CO}_{3}+3 \mathrm{O}_{2}+4 \mathrm{Na}_{2} \mathrm{CrO}_{4}+\mathrm{CO}_{2}$

(Roasting of chromate ore with soda ash)

$\mathrm{Pb}\left(\mathrm{NO}_{3}\right)_{2}+\mathrm{Na}_{2} \mathrm{CrO}_{4}+\mathrm{PbCrO}_{4}+2 \mathrm{NaNO}_{3}$

(Medium chrome yellow pigment)

\section{or}

$2 \mathrm{~Pb}\left(\mathrm{NO}_{3}\right)_{2}+\mathrm{Na}_{2} \mathrm{Cr}_{2} \mathrm{O}_{7}+\mathrm{H}_{2} \mathrm{O} \rightarrow 2 \mathrm{PbCrO}_{4}+2 \mathrm{NaNO}_{3}+2 \mathrm{HNO}_{3}$

Light chrome yellow pigments are produced as follows [13]:

$2 \mathrm{~Pb}\left(\mathrm{NO}_{3}\right)_{2}+\mathrm{Na}_{2} \mathrm{CrO}_{4}+\mathrm{Na}_{2} \mathrm{SO}_{4}+\mathrm{PbCrO}_{4} \cdot \mathrm{PbSO}_{4}+4 \mathrm{NaNO}_{3}$. 


\subsection{EFFECT OF CHROMATES ON WORKERS IN THE MANUFACTURING PROCESS}

European, American and Japanese reports have discussed the effects of chromate pigments on workers involved in the manufacturing process. Enterline [5] cites the work of Machle and Gregorlus as the earliest published epidemiological investigation of respiratory tract cancer among chromate workers in the U.S. Machle and Gregorlus [6] studied the mortality experfence of workers in seven U.S. plants engaged in the extraction of chromium from chromate ore. Enterline lists a table showing annual mortality rates for $81 x$ of these plants. For the period 1943-1947, chromate workers were dying of cancer of the respiratory tract at a rate over twenty times that for ofl refinery workers. Enterline also cites the work of the U.S. Public Health Service (USPHS) in 1ts study of the same six chromate plants for the period 19401948 [7] Nearly 29 times as many deaths from respiratory tract cancer were reported as would have been expected based on mortality rates of U.S. males. In a Litton Industry study [8] complled by Sullivan, the authors, commenting on the same USPHS study, stated there were 470.8 deaths $/ 100,000$ in the chromate 1ndustry as compared w1th $16.7 / 100,000$ of the same age group in the U.S. Th1s study reported that an examination of the bodies of chromate workers showed that they had acumulated appreciably higher concentrations of chromium than the general population. It also mentioned the findings of Baetjer [9] who stated that an examination of the lung tissues of these workers Indicated that carcinogenic tissues were not always associated with the higher concentrations of chromium. The Litton study concluded that Individual susceptibility plays an important role in cancer induced by chromium compounds. As cited by Enterline [5], a later study on three chromate-producing plants by the University of Pittsburgh was the only study in which workers were examined after leaving the 1ndustry. From 1200 chromate workers there were 69 cases of respiratory cancer. Enterline [5] stated further that the old chromate-producing 
plants upon which the American epidemiological data were based had been either dismantled or completely rebullt. He concluded that for the plants which remain it is too early to tell whether the changes made have completely eliminated the excess respiratory tract cancer. Utidjian [10] discusses two plants engaged in chromate production. One plant produced sodium dichromate from chromite ore, while the second plant produced chromic acid and basic chromic sulfate from the sodium dichromate. In the plant producing the dichromate, the incidence of death from lung cancer was 18 times normal. There were no lung cancer cases in the second plant. There has been no mining of chromite ore in the U.S. since 1961 because higher grade ore can be purchased from foreign countrles at lower cost. Bidstrup and Case [11] reported that, from 723 workers in three chromate plants in Great Britain, there were twelve deaths from lung cancer compared with 3.3 expected on the basis of the total populations. Enterline commented that the difference between this study and [11] previously cited studies of workers in the U.S. Is striking and may be due to better working conditions or to a shorter follow-up period in the study by Bidstrup and Case.

Oettel et al. [12] discussed the statistics concerning lung cancer among workers in a small chromate factory in Ludwigshafen. They mentioned that the pathologist, Hanser, in Ludwigshafen, reported that, of 16 cases of lung carcinoma which occured between 1921 and 1928, five came from a chromate operation. The exposure times for the chromate workers were 5-27 years. The regular induction time for lung carcinoma was estimated to be 20-30 years. However, these workers had also handled quinones which are very carcinogenic. Oettel et al. said it appeared that chromates caused lung cancer primarily in combination with other cancer-causing products as in the case of smokers. No more chromates are manufactured there. 
Capodaglio et al. [13] reported that workers exposed continually to chromates had modules of insoluble powder in the lung. Respiratory problems attributed to hexavalent chromium were laryngitis, chronic bronchitis, and elevated incidence of tumors in the respiratory tract after a period of exposure to production of dichromates from chromates from 5 to 27 years. Eighty-eight people, 22-58 years of age, were examined. No statistics on the number of fatalities were given. Renovation of the air circulatory system was followed by an outstanding decrease in dust pollution.

Pica [14] and Hartogensis and Ziehlhius [15] carried out toxicity studies on lead chromate but their primary concern was lead rather than chromate toxicity.

Pica [14] reported that lead poisoning is one of the hazards workmen face in ceramic dye factories. The reason is that basic lead chromate $\left(\mathrm{PbCrO}_{4} \cdot \mathrm{PbO}\right)$ is a raw material for a red ceramic dye. Examinations were performed on 161 men, 16-62 years of age, who had been working in a ceramic dye factory for 1-21 years. Clincial and laboratory results from men engaged in different phases of work were tabulated. Workmen engaged in fusing and sifting of the raw material were found to be subject to the greatest risk. An abstract of Pica's paper is given by Campbell and Mergard in the EPA publication "Biological Aspects of Lead." [16]

Hartogensis and Zielhuis [15] discussed the effect of exposure to lead chromate dust on 26 male workers in two pigment factories. Seven workers were exposed to less than $0.1 \mathrm{mg} \mathrm{Pb} / \mathrm{m}^{3}$ (Group A), five to $0.1-0.2 \mathrm{mg} \mathrm{Pb} / \mathrm{m}^{3}$ (Group B) and fourteen to greater than $0.2 \mathrm{mg} \mathrm{Pb} / \mathrm{m}^{3}$ (Group C). The hemoglobin (Hb) level was clearly subnormal in Group C. The authors conclude that the maximum allowable concentration (MAC) for lead chromate should be 0.1 to $0.2 \mathrm{mg} \mathrm{Pb} / \mathrm{m}^{3}$, using the $\mathrm{Hb}$ decrease as a criterion. 
They sald that, because the same MAC had been established for other lead pigments, the toxicity for all lead pigments, both soluble and insoluble was similar. An abstract for the paper by Hartogensis and Zielhuis is given by Campbell and Mergard In the EPA publication "Blological Aspects of Lead." [17]

A report translated from Japanese summarizes lung cancer statistics for workers in a chromate plant in Japan [18]. The chromate factory was in operation from 19361973. Of a total of 554 workers, 133 were exposed to chromates for ten years or more. Of the 133, ten cases of cancer occured; four were lung cancer and, s1x, cancer of the bronchial tubes.

A later report [19] discusses lung cancer in a chromate factory in Japan for the period 1972-1976. Ten patients with lung cancer were among workers in a chromate factory. Four additional cases were found through death certificates and medical records. Most of these were smokers and all were men. The average duration of exposure to chromates was 24 years. The primary sites of the cancer were in the large bronch1 in the ten patients. The cell type was squamous (scale-like) in seven patients and small anaplastic (having high reproductivity) in three. The incidence (person per year) calculated from the number of employees, duration of factory activity, number of cancer patients and shortest duration of labor period among the patients was 657.9 per 100,000 compared to 13.3 per 100,000 In Japan as a whole.

Fraumeni [20] discussed chemical carcinogenesis in man due to industrial exposure and clted the work of Machle and Gregorlus, Baetjer, B1dstrup and Case In their studies of the cancer hazard among chromate workers. He sald than an elevated risk of lung cancer had been linked to the chromate pigment industry in Norway [21]. The risk was not increased among chromite-ore miners but only among workers producing and processing chromium compounds. 
Langard and Norseth [21] conducted a study of bronchial cancer among workers in a small company in Norway which produced chromate pigments. The company had employed 133 workers from the time production started in 1948 until the end of 1972 . The study was conducted on 24 workers who had been exposed to chromate dust for more than three years. Three of these workers developed lung cancer. One had been employed for six years and had been exposed to both lead and zinc chromate pigment. The other two had been employed for elght years and had been involved in the manual mixing of solium dichromate. Two of the three workers were smokers. The authors commented that 1 was difficult to judge to what extent the smoking habits of two of these workers may have contributed to their lung cancers.

A follow-up study of mortality among workers at three English chromate plgment factorles was performed by the Division of Epldemiology, Institute of Cancer Research [22]. Two factories made both lead chromate and zinc chromate and workers were exposed to both substances. The third factory made only lead chromate. Workers were, for the purposes of this survey, classifled by degree of exposure to chromates. Work in the "dry" departments where pigments were ground, blended and packed was classified as high. Medium classification covered work in the less dusty "wet" compartments where precipitates were washed, pressed and stove-dried. In the low classification, there was only slight exposure to chromates, e.g. most laboratory jobs, painting, bricklaying. In the two factorles producing both lead and zinc chromate, there was a marked excess of lung cancer deaths. These occured among workers within 5-25 years after the first exposure even if employed for as little as one year. Under conditions prevalling at the third factory since 1946, lead chromate appeared not to have caused lung cancer deaths. In the author's opinion, 
the results suggest that the manufacture of zinc chromate may involve a lung cancer hazard, although improved working conditions at one factory appear to have controlled this hazard from about 1955 .

In the National Academy of Science (NAS) study on chromium [23], the authors discussed the work of $\mathrm{W}$. C Hueper on occupational respiratory tract cancer. Heuper had a history of 187 cases of cancer in which the workmen handled chromates. Only seven of these 187 did not have cancer of the lung. The study cited Hueper who found that, in 123 cases of lung cancer in chromate workers around the world, cancers were not of any single histologic type. There were 46 squamous-cell carcinomas, 66 round-cell carcinomas and 11 adenocarcinomas. One of the conclusions of the NAS study was that the carcinogens present in the chromate manufacturing process have not been identified.

The results of industrial exposure to mixed chromite and chromate compounds have been summarlzed by UtIdjian [10]. These included dermatitis, perforation of the nasal septum, inflammation of the lining of the eyelids and cancer of the lung.

Deichmann and Gerarde [24] stated that the results of the skin contact with hexavalent chromium compounds (chromates, dichromates) may be dermatitis and slow-healing ulcers. They warned that prolonged or repeated inhalation of mists or dusts will result in perforation of the nasal septum. They indicted chromates as a group of chemicals capable of inducing pulmonary carcinoma in man.

Rauscher [25] commented that there was a direct relationship between lung cancer and cigarette smoke and other inhalation hazards. He defined these as asbestos, 
chromates and radioactive materials. Grawey [26] stated that, "the strong supportive data for a relationship between hexavalent chromium and lung cancer come from chromate-producing industries, not from chromic acid exposures."

\subsection{EFFECTS OF LEAD-CONTAINING SPRAY-APPLIED PAINTS ON PAINTERS WORKING IN CONFINED AREAS}

Neronski1 [27] reported the effect of lead-containing spray applied paints on painters. These men were spray painters employed in an auto factory. The lead content of the air in the workroom was 0.004 to $3.452 \mathrm{mg} / \mathrm{m}^{3}$ (greater than 0.01 in $96.7 \%$ of the samples), and solvent vapor concentrations were benzene 0.02 to 0.45 $\mathrm{mg} / \mathrm{l}$, toluene 0.02 to $0.32 \mathrm{mg} / \mathrm{l}$, and naphtha solvent 0.04 to $0.71 \mathrm{mg} / \ell$. The aromatic hydrocarbon content of the air exceeded permissible levels in $67.9 \%$ of the cases. Physical examinations were performed on 216 painters whose duration of employment ranged from several months to twelve years. Of these $9.7 \%$ showed signs of chronic lead poisoning. The signs of chronic effects of benzene and its homologs were also observed. The author concluded that health hazards were caused not only by the lead pigment but by the solvents in the paint. To elimate these health hazards, he recommended that lead-free paints be substituted for the lead-containing paints and that solvents other than benzene and its homologs be used.

Ankerst and Weimer [28] discussed hazards in the enamel industry. Listed among the toxic raw materials were red lead oxide, lead carbonate and lead silicate. The authors cited the lethal dose of lead as between 11 and $27 \mathrm{~g}$. They warned that daily inhalation of approximately $1 \mathrm{mg}$ of lead would result in abdominal and muscular pain, paralysis and liver damage. The authors said that, while lead compounds have been largely eliminated as raw materials in the enamel industry and precautionary 
measures have been taken where they are still used, the complete exclusion of lead compounds should be implemented; they sald that the introduction of lead-free pottery shows this to be feasible.

Zielhuis [29] discussed the toxicity, on the basis of existing literature, of many raw materials used in the paint industry-binders, pigments including lead pigments, drfers, solvents, diluents and plasticizers. The work has carried out as an aid to dermatologists involved in treating skin diseases caused by these substances. He stated that, before 1930, lead polsoning was the most serlous disease for painters. He mentioned the hyglenic precautions which we re gradually introduced. These were washing hands before eating, not sanding old paint residues or surfaces, using paste pigments instead of powders and using a respirator when burning off paint. He quoted the work of 0ltramare who described two cases of lead polsoning in which two workmen removed lead paint by sanding without wearing masks. For painters using palnts contalning chrome yellow or chrome green pigments, the only forms of poisoning have been related to the $8 \mathrm{kin}$. Cases of erosion of the nasal septum caused by chromic acld and chromate dust occur only in plgment factories and not in paintproducing or paint-using industries. Zielhuis said that this was because the precautions taken against lead polsoning were sufficlent to prevent chromate damage to the nose and skin. The danger of lung cancer which was present in industries working with chromite ore and with plgments "was probably" not present for people who produce and use paint.

Two methods of spray painting without using compressed alr for atomizing the paint have been ut1lized. One method, employs hydraulic pressure alone ("high-pressure method") and the other hydraul1c pressure and heating the paint to reduce the viscosity ("heat-with-pressure method"). Proper ventilation for both of these 
methods had been a source of much concern to industrial hygienists. A study was conducted by Berghout [30] to indicate the health, safety and fire hazards assoclated with the use of these methods. The primary objective was to determine whether an air velocity of less than $150 \mathrm{ft} / \mathrm{min}(76 \mathrm{~cm} / \mathrm{sec})$ could be applied in the ventilation control of spray booths, the extent of the health hazard being used on the concentration in the breathing zone of mist containing lead or zinc chromate pigment and vapor from the thinner. Vehicle spraying with lead-bearing paint by the "highpressure method" produced lead concentrations averaging $2.5 \mathrm{mg} / \mathrm{m}^{3}$ at air velocities of $105 \mathrm{ft} / \mathrm{min}(53 \mathrm{~cm} / \mathrm{sec})$ and $3.5 \mathrm{mg} / \mathrm{m}^{3}$ at $130 \mathrm{ft} / \mathrm{min}(66 \mathrm{~cm} / \mathrm{sec})$. Vehicle spraying with lead-bearing paint by the "heat-with-pressure method" produced concentrations averaging $4.4 \mathrm{mg} / \mathrm{m}^{3}$ at $62 \mathrm{ft} / \mathrm{min}(31 \mathrm{~cm} / \mathrm{sec})$ and $0.5 \mathrm{mg} / \mathrm{m}^{3}$ at $105 \mathrm{ft} / \mathrm{min}(53 \mathrm{~cm} / \mathrm{sec})$. Missile container spraying with lead-bearing paint by the "high-pressure method" produced concentrations of lead averaging $2.3 \mathrm{mg} / \mathrm{m}^{3}$ at $62 \mathrm{ft} / \mathrm{min}(31 \mathrm{~cm} / \mathrm{sec})$ and $3.3 \mathrm{mg} / \mathrm{m}^{3}$ at $105 \mathrm{ft} / \mathrm{min}(53 \mathrm{~cm} / \mathrm{sec})$ by the "heat-with-pressure method. Open shop spraying of vehicles by the "high-pressure method" produced lead concentrations averaging $3.2 \mathrm{mg} / \mathrm{m}^{3}$ and solvent vapor concentrations of $590 \mathrm{ppm}$. Using the "heatwith-pressure method," lead concentrations average $5.9 \mathrm{mg} / \mathrm{m}^{3}$ and solvent vapor concentrations averaged $800 \mathrm{ppm}$. The air velocities were not determined. From the results obtained on analysis of air samples during spraying operations, the author concluded that, at low rates of ventilation in vehicle spraying, personnel required the protection of paint-spray respirators; also at air velocities less than 100 $\mathrm{ft} / \mathrm{min}(51 \mathrm{~cm} / \mathrm{sec})$, dangerous concentrations of explosive vapors were recorded. For missile container spraying, a ventilating rate of at least $150 \mathrm{ft} / \mathrm{min}$ (76 $\mathrm{cm} / \mathrm{sec}$ ) was required, and higher when bottom sides were sprayed. In open-face booths, a ventilating rate of at least $150 \mathrm{ft} / \mathrm{min}(76 \mathrm{~cm} / \mathrm{sec})$ should be maintained. Results in open shop spraying of vehicles indicated danger from every standpoint. 
A report on a survey of 50 paint plants by the Cleveland Bureau of Industrial Hyglene to determine the amount of lead exposure, showed the value of adequate ventilation [31]. Lead paints were manufactured in 28 plants on a routine basis. A few other plants made several batches a month. In one plant, $16001 \mathrm{bs}$ (726 kg) of a combination of lead and $z$ inc plgments was used in paint formulation several times a week. Analysis of air samples taken in the area where workmen were emptying bags of these plgments showed an excess of $8 \mathrm{mg} \mathrm{Pb} / \mathrm{m}^{3}$. There was only one reported case of lead polsoning which resulted in the death of the workman but the anonymous author sald there were undoubtedly many cases which were never reported. After local exhaust ventilation was installed in this plant, a1r samples taken from the same area were found to contain $0.16 \mathrm{mg} \mathrm{Pb} / \mathrm{m}^{3}$. In plants where exposure had been much greater, with installation of ventilation, lead reduction was even more pronounced. Abstracts of reference 22 through 26 are given in "B1ological Aspects of Lead." [32].

A health hazard evaluation determination was conducted by NIOSH at the Peabody Galion Corp, Unisteel Body Division, L1ma, Oh1o [33]. It was determined that employees were exposed to potentially toxic concentrations of lead in association with spray painting operations at this plant. Employee exposure to lead was in excess of the federal occupational health standard for elght hour time-weighted average exposure of $0.2 \mathrm{mg} / \mathrm{m}^{3}$. It was concluded that employee exposure to chromium did not appear to be excessive. As reflected by total airborne paint particulate concentrations, spray painting employees were exposed to excessive levels of paint overspray. In interviewing the employees it became obvious that they had not been properly instructed in the wearing, function and maintenance of their respiratory protective equipment. It was also recommended that filters in spray booths be 
changed frequently and where possible, spray painting should be conducted so that the painter sprays toward the booth fllters. Booths where large objects are painted should be equipped with additional exhaust ventilation.

A health hazard evaluation was also conducted by NIOSH at the Harris Structural Steel Co., Piscataway, N.J. [34]. Bridge girders were painted with lead silico chromate paint which was applied by alrless spray. Prior to painting, the girders were prepared by workers who cleaned and ground each girder. From the analysis of air samples, the exposure of the spray painter to lead was judged to be great enough to cause adverse health effects, if unprotected. Exposure to chromium and iron was judged to be at safe levels. The following recomendations were made (1) Workers performing spray painting with lead paint should have their blood analyzed for lead annually or urine analyzed for lead semi-annually, (2) an approved respirator should be used by spray painters while palnting with lead silico chromate paint (Bureau of Mines Schedule 21B), (3) workers should wash hands and face thoroughly before eating and no food beverages or tobacco should be permitted in the work area, (4) workers should be provided with clean work clothes on a daily basis with thorough showering after work before changing into street clothes.

Walgren [35] listed the solubility of chromium yellow light pigment and chromiun yellow medium pigment in "hydrochloric acidic water" with a pH of 3 and 1 and "assumes that the risk of poisoning would depend upon getting the soluble pigments down to the stomach." He said the risk of release is considerably lessened by the encapsulating film surrounding the pigment grains in the paint and therefore the lead pigment powder and paint with lead pigment should be distinguished. He cited the normal lead content in the blood as between $0.1-0.5 \mathrm{ppm}$. 


\subsection{BIOLOGICAL INTERACTIONS OF CHROMIUM AND CHROMATES}

The authors of the National Academy of Sclence study on chromium [36] stated that chromium is an essential trace element for humans and animals. Hexavalent chromium 1s a strong oxidizing agent which reacts readily with organic matter in acidic solution while being reduced to the trivalent form. The NAS authors sald that the well known toxic action of chromates was due largely to ths oxidizing action. Hexavalent chromium also had the property of easy penetration of biologic membranes. These two properties distingulshed hexavalent chromium from the trivalent form which is much less toxic.

The authors stated that all the blologic interactions of chromate should result in reduction to the trivalent form and later coordination to organic molecules. Hexavalent chromium is reduced within human skin to the trivalent state by methionine, cystine and cysteine. Chromates penetrate the red blood cells, are reduced to the trivalent form and bound to hemoglobin, resulting in a stable tagging of the red blood cells. The author stated that there was some evidence that chromfum could exist in other valence states but there was no evidence that they played a role in blologic systems. They concluded that chromium in biologic material rapidly attalned the trivalent form. Hansen [37] sald that, wh1le small quantities of chromium are essential, larger concentrations are toxic. Inhalation is the main way of absorbing 1t. The toxicity depends on the valence state of the metal. Generally speaking, the metal 1tself is inactive. The greatest risk is from hexavalent chromium which is toxic for all body cells. He commented on reports which told of a high incldence of lung cancer where exposure to hexavalent chromium had occurred. He stated that normal blood levels of chromium were $1.05-5.5 \mathrm{\mu g} / 100 \mathrm{ml}$. 


\subsection{ANIMAL STUDIES WITH HEXAVALENT CHROMIUM}

The National Academy of Science study [36] reported on the work of Feldman [38] who found that all hexavalent chromium injected intravenously into rats was rapidly reduced. The same reduction occurred when hexavalent chromium was added in vitro to rat tissues. The NAS authors also mentioned the work of Laskin, Kuschner and Drew $[39,40]$ who tested the carcinogenic properties of the chromate ore roast residue, calclum chromate, chromic chromate, chromic oxide and chromic trioxide. Their technique consisted of using a very small capsule made of tine steel wire mesh which was impregnated with the test chemical, and mixed in equal parts with cholesterol. "This capsule was attached permanently with a fishhook to the inner wall of the lower-lobe bronchus of the test rat in such a way as not to cause obstruction." Six of the 100 rats exposed to calcium chromate developed squamouscell carcinoma of the bronchus and two of them developed adenocarcinoma. One of the 100 rats developed squamous-cell carcinoma when exposed to roast residue. All other compounds were without effect. The tumors were invasive and some metastasized (spread to other parts of the rat). Mean duration for exposure of the six carcinomas caused by calcium chromate was 540 days and the duration for the two adenocarcinomas were 366 and 609 days.

The NAS authors included the work of Roe and Carter [41] who tried repeated intramuscular injections of calcium chromate in arachis oll for a 20 week period and produced sarcomas at the point of injection. These tumors were invasive but did not metastasize.

Nettesheim et al. [42] reported results on experiments with mice exposed for 5 hrs/ day, 5 days/week for their lifetime to fine calcium chromate dust (70\% of particles smaller than $0.3 \mu \mathrm{m})$, at a concentration of $13 \mathrm{mg} / \mathrm{m}^{3}$. Control mice were exposed 
to filtered air. The mice developed pulmonary adenomas at an earlier age than control mice and had four times as many tumors. This work was also discussed by the NAS authors. They said also that it had been demonstrated that, in experiments with rats, invasive sarcomas (fleshy tumors) could be produced locally by implantation of a relatively insoluble hexavalent chromlum compound in a medium that holds the chemical in contact with the area. They considered it much more significant that production of squamous-cell (scale-like) carcinoma of the bronchus in rats had been produced by local implantation of calcium chromate in cholesterol pellets. They concluded that, although calcium chromate was the specific chromium compound responsible for cancer of the bronchus in rats, it would be "premature to say that only this form of chromium can exert a carcinogenic effect."

Enterline [5] stated that "recent animal experiments suggest that the carcinogenic agent in the old chromate producing plants was calclum chromate." He stated that further epidemiological studies were needed to verify this.

A Midwest Research Institute study [43] on lead paint ingestion consisted of feeding studies in which rats were fed rat chow mixed with different concentrations of lead-containing paints as $0.1 \%$ of their diet. Used in the study were a control palnt with no lead, paints containing $0.08 \%$ lead octoate, $0.53 \%$ lead octoate, $2.05 \%$ lead octoate, $0.42 \%$ lead chromate, $1.95 \%$ lead chromate, $12.43 \% 1$ ead chromate, $66.05 \%$ lead carbonate, and NBS lead paint ( $11.92 \%$ lead carbonate). Rats were examined after 4,8 and 13 weeks. Both the $66.05 \%$ lead carbonate and the NBS lead paint produced the signs of lead poisoning in rats, 1.e., decrease in red blood cells, and significant increases in blood, kidney, bone, liver, and brain lead. With the 
other formulations, the only evidence of toxicity was in the rats fed the $12.43 \%$ lead chromate. This consisted of an increase in blood lead without other signs of poisoning.

Lead chromate was investigated for its carcinogenic potential in both rats and mice in a study performed at the Institute of Chemical Biology, University of San Francisco [44]. Results show that this compound is a potent carcinogen in rats when administered intramuscularly (i.m.). Sixty four percent of the animals treated developed malignant tumors at the injection site. Three renal carcinomas were also found after $i . m$. treatment with lead chromate. Since lead powder is a comparatively weak carcinogen in rats, whether given orally (p.o.) or i.m., the authors suggest that the combination of lead and chromium (also a weak carcinogen) in lead chromate accounts for the high carcinogenic activity of this compound in rats. Swiss albino female mice could not tolerate the same high dose level as the rats. At the lower dose administered to the mice, no tumors were detected. The mechanism of the action of lead compounds as renal carinogens is unknown, but porphyrin metabolism is disturbed.

Ninety-day feeding studies were conducted using 6-month-old beagle dogs to determine the toxicologic effects and tissue residues resulting from ingestion of lead-containing pigments [45]. The pigments were lead carbonate, light chrome yellow (80\% lead chromate \& $20 \%$ lead sulfate), medium chrome yellow (lead chromate), primrose chrome yellow ( $60 \%$ lead chromate \& $40 \%$ lead sulfate), and molybdate orange $(80 \%$ lead chromate, $15 \%$ lead molybdate and $5 \%$ lead sulfate). Groups of four dogs of each sex were fed each pigment at dietary levels of either 2000,5000 or 20,000 ppm. Early signs of lethargy, anorexia (loss of appetite), dehydration and emaciation followed by hyperirritability, disorientation, motor ataxia and convulsions preceding 
death were seen in animals fed 2000 ppm or greater of lead carbonate, 5000 ppm or greater of light chrome yellow, primrose chrome yellow or molybdate orange and $20,000 \mathrm{ppm}$ of medium chrome yellow. All the chemicals tested produced decreased hemoglobin concentration and altered erythrocyte morphology, although the level of exposure to produce these changes varied considerably. Also involved were pathologic changes of the kidney and cell changes. These occurred with all five pigments. The most severe lesions with the shortest period of onset occurred with lead carbonate. It was concluded that although the biological effects produced by the five chemicals were similar, the quantitative aspects (dose needed to produce the changes) are quite different.

\subsection{AIR POLLUTION STUDIES RELATING TO CHROMIUM}

Magee [46] sald that there were large number of different chemicals known to cause cancer in experimental animals but relatively few for which there was convincing evidence of carcinogenic activity in man. He quoted a list by Hueper of recognized carcinogens. This list included asbestos, arsenic, chromium, nickel, benzene, some aromatic amines, coal tar pitch, soot, and mustard gas.

Woolrich [47] commented that "the principal harm done by the less desirable metals 1s that they tend to displace physiologically desirable elements belonging to the same periodic group. Barium and berylium inhibit absorption of calcium and strontium displaces calcium. Some elements accumulate with age, notably aluminum, barlum, tin, and titanium but do not normally reach dangerous levels. Some such as chromium and vanadium are retained in the lungs in insoluble form." 
Shakman [48] stated that high levels of chromium were found in the air of heavy industrialized areas. Chromium also occurred in water supplies as a minor contaminant. It occurred abundantly in tobacco smoke. Shakman commented on the variation in the uptake of chromium from the soll by plants. Corn rejected hexavalent chromium. Tobacco, on the other hand, selectively absorbed it.

According to Dreisbach [49], the fatal dose of a soluble chromate such as potassium chromate, potassium dichromate or chromic acid was approximately $5 \mathrm{~g}$. The threshold limit value (TLV) for chromium (determined as chromic oxide) in air was $0.1 \mathrm{mg} / \mathrm{m}^{3}$.

The authors of the Litton Industry report [50] stated that the exact sources of chromium in air pollution were not known. The possible sources cited are the metallurgical industry, chromate-producing industry, chrome plating, burning of coal and the use of chromium chemicals such as fuel additives, corrosion inhibitors, pigments, tanning agents, chromium mordants in the textile industry, fungicides, wood preservatives, and rust inhibitors in cooling-tower recirculating water systems. Other sources of chromium pollution are from asbestos, welding rod fumes and cement dust. In 1964, atmospheric concentrations of total chromium averaged $0.015 \mu \mathrm{g} / \mathrm{m}^{3}$ and ranged as high as $0.0350 \mu \mathrm{g} / \mathrm{m}^{3}$. No evidence of damage by airborne chromium to animals or plants had been found [51].

The NAS authors stated that the concentration of chromium in the ambient air of large industrial cities of the U.S. usually ranged from 0.01 to $0.03 \mu \mathrm{g} / \mathrm{m}^{3}$ and in nonurban areas it was less that $0.01 \mu \mathrm{g} / \mathrm{m}^{3}$ [52]. The concentration of chromium in the soil varied from tracers to $250 \mathrm{ppm}$ as $\mathrm{CrO}_{3}$ although concentrations as high as $3900 \mathrm{ppm}$ had been reported in the literature. The total chromium intake per day by man had 
been estimated as 5 to $115 \mu \mathrm{g}$ in food and water and 0.04 to $0.08 \mu \mathrm{g}$ in a1r. There were no known harmful effects from the chromium in the ambient air or from dietary int ake.

Linton et al [53] have established that toxic trace elements such as As, Be, Cd, Cr, $\mathrm{Mn}, \mathrm{N} 1, \mathrm{~Pb}, \mathrm{Sb}, \mathrm{Se}, \mathrm{Tl}, \mathrm{V}$ and $\mathrm{Zn}$ are being discharged in the atmosphere in association with particles emitted from fossil fuel combustion and conversion. It has also been shown that the specific concentration of many of these elements (in micrograms per gram of fly ash) increase with decreasing particle size in fly ash derived from coal combustion. Consequently, the highest trace element concentrations are encountered in small particles which most readily pass through control devices, which remain suspended in the atmosphere for long periods and which deposit in the innermost regions of the human respiratory tract when inhaled. These results are of real significance because they show that conventional bulk analyses provide a poor measure of the actual concentrations of many toxic trace elements that are in effective contact with the external environment of a particle.

The American Standards Association (ASA), now called the American National Standards Institute (ANSI), American Conference of Governmental Industrial Hygienists (ACGIH) and Occupational Safety and Health Administration (OSHA), have all set 11mits for chromium concentration in air of industrial plants [54]. For all three the limit for chromic acid and chromates, as $\mathrm{CrO}_{3}$ is $0.1 \mathrm{mg} / \mathrm{m}^{3}$; for $\mathrm{AGGIH}$ and OSHA, the limit for chromium as soluble chromic and chromous salts as $\mathrm{Cr}$ is $0.5 \mathrm{mg} / \mathrm{m}^{3}$, chromium metal and insoluble salts as $\mathrm{Cr}, 1.0 \mathrm{mg} / \mathrm{m}^{3}$, and for ACGIH some insoluble chromates $0.1 \mathrm{mg} /{ }^{3}$. The National Institute of Occupational Safety and Health has issued recommended limits for hexavalent chromium [55]. Those chromium compounds which are considered as non-carcinogenic are the monochromates and dichromates of $\mathrm{H}, \mathrm{Li}, \mathrm{Na}$, 
$\mathrm{K}, \mathrm{Rb}, \mathrm{Cs}, \mathrm{NH}_{4}$, and $\mathrm{Cr}^{+6}$ oxide (chromic acid anhydride). All the rest are considered to be carcinogens. For carcinogens, the maximum allowable concentration is $25 \mu \mathrm{g}$ $\mathrm{Cr}^{+6} / \mathrm{m}^{3}$ as a time weighted average exposure for up to a 10 hour work day, 40 hour work week. For non-carcinogenic compounds, the maximum allowable concentration as determined by a 15 minute sample is $50 \mu \mathrm{g} \mathrm{Cr} / 6 / \mathrm{m}^{3}$.

\subsection{WATER POLLUTION STUDIES RELATING TO CHROMIUM IN RUNOFF FROM STREETS}

Sarter and Boyd [56] discussed pollution aspects of storm water runoff in an EPA report. They stated that the street surface runoff for the hypothetical city following one hour storm $[0.5$ inch $(1.27 \mathrm{~cm})$ of rain] would contribute considerably more pollution load than the city's sanitary sewage during the same time. They defined a hypothetical city as one having a population of 100,000 people, total land area of 14,000 acres (5,666 hectares), land-use distribution of $75 \%$ residential, $5 \%$ commercial, and $20 \%$ industrial. It has 400 curb miles ( 644 curb $\mathrm{km}$ ) of streets (tributary to receiving waters) and a sanitary sewage output of $12 \times 10^{6} \mathrm{gal} / \mathrm{day}$ $\left(4.54 \times 10^{6} \mathrm{\ell} /\right.$ day). The streets are cleaned (intentionally or by rainfall) every 5 days.

The calculated quantities of pollutants which would enter the receiving waters of a hypothetical city from the street surface runoff following a one-hour storm were compared with pollutants from raw sanitary sewage and are listed below. The metals were analyzed to determine total quantity, not specific chemical form. From the data given by Sarter and Boyd, table 8.1 was prepared.

Sarter and Boyd [56] also determined the metal content of street surface contaminants for seven selected communities. These were San Jose, Phoenix,, Milwaukee, Baltimore, Seattle, and Atlanta. The weighted averages in $\mathrm{ib} / \mathrm{curb} \mathrm{mile}(\mathrm{kg} / \mathrm{curb} \mathrm{km})$ for metals 
were as follows: chromium 0.11 (0.03); copper $0.20(0.06)$; zinc 0.65 (0.18); nickel $0.05(0.014)$; mercury $0.073(0.02)$; lead $0.57(0.16)$. Total heavy metals per curb m1le was $1.61 \mathrm{~b}(0.45 \mathrm{~kg} / \mathrm{curb} \mathrm{km})$. The sampling was random. They could not determine the time period for accumulation of the contaminants. The authors commented that the fact that the weighted average of the total heavy metal was as high as $1.61 \mathrm{~b} /$ curb mile $(0.45 \mathrm{~kg} /$ curb $\mathrm{km})$ was "rather alarming."

Sarter and Boyd stated that the sources of the street surface contaminants included pavement, motor vehicles, atmospheric "fallout," vegetation, runoff from adjacent land areas, litter, spills, and anti-skid compounds. The contaminants included asphaltic and portland cement, their various products of decomposition and aggregate materials. Also included were small amounts of road marking paints, crack fillers and expansion joint compounds. On a weight basis, aggregate materials accounted for the largest contribution of materials from the pavement.

Sarter and Boyd commented that one of the most important findings of their study was that a great portion of the pollution potential was associated with the fine solids fraction of the street surface contaminants. Very fine silt-like material (less that 43 microns) accounted for only $5.9 \%$ of the total solids. It also accounted for over $1 / 2$ of the heavy metals, nearly $3 / 4$ of the total pesticides, $1 / 4$ of the oxygen demand, and $1 / 3$ to $1 / 2$ of the algal nutrients.

Depression of dissolved oxygen was one of the most significant detrimental effects a pollutant could have on receiving waters. Subtantial loads of oxygen demanding substances could lead to fish k11ls, foul odors, and slime growth. Heavy metals were of concern because of their potential toxicity to various biological forms. Also they destroyed the bacteria necessary in the activated sludge process. 
Table 8.1

Street Surface Runoff

(following $1 \mathrm{hr}$ storm)

$1 \mathrm{~b} / \mathrm{hr}$

560,000

5,600

13,000

Chemical oxygen

demand ( $C O D$ )

Kjeldhal nitrogen

Phosphates

Zinc

Copper

Le ad

Nickel

Mercury

Chromium

Total coliform

bacteria (org/hr) $\mathrm{kg} / \mathrm{hr}$

Raw Sanitary Sewage

$\mathrm{lb} / \mathrm{hr}$

$\mathrm{kg} / \mathrm{hr}$

$254,016 \quad 1,300$

590

$2,540 \quad 1,110$

499

$5,897 \quad 1,200$

544

880

300

210

95.3

440

200

50

22.7

260

118

0.84

0.38

80

36.3

0.17

0.08

230

$104 \cdot 3$

0.13

0.06

20

9.1

0.04

0.02

29

13.1

0.27

0.12

44

0.08
0.17

20.0

$460,000 \times 10^{10}$ 
The authors, is discussing the heavy metals, said that zinc and lead had the heaviest loadings, chromium and nickel the lightest. These trends were borne out in all the cities tested. The arithmetic mean for lead was $0.681 \mathrm{~b} / \mathrm{curb}$ mile $(0.19$ $\mathrm{kg} / \mathrm{curb} \mathrm{km})$ and for chromium $0.12 \mathrm{lb} / \mathrm{curb} \mathrm{mile}(0.033 \mathrm{~kg} / \mathrm{curb} \mathrm{km})$. For all metals except mercury, loading intensities (in lb/curb mile) were heaviest in industrial areas and lightest in commercial areas. The loading intensities for lead in street surfaces ranged from a low of $0.030 \mathrm{lb} / \mathrm{curb} \mathrm{mile}(0.008 \mathrm{~kg} / \mathrm{curb} \mathrm{km})$ (Tulsa) to a high of $2.01 \mathrm{~b} / \mathrm{curb} \mathrm{mile}(0.56 \mathrm{~kg} / \mathrm{curb} \mathrm{km}$ ) (San Jose). There was a strong tendency for lead to be associated with solids of a small particle size range. Nearly $90 \%$ of the total lead found was with particles smaller than 246 microns. It was not known whether the lead existed in a compound whose particles were of this size or if the lead was adhering to particles of this size. The USPHS drinking water standards $11 \mathrm{mit}$ lead to $0.05 \mathrm{ppm}$. Chromium was not found in substantial quantities in street surface contaminants. Loading intensities ranged from $0.0033 \mathrm{lb} / \mathrm{curb}$ mile $(0.0009 \mathrm{~kg} /$ curb km) (Tulsa) to $0.451 \mathrm{~b} /$ curb mile $(0.126 \mathrm{~kg} /$ curb km) (Baltimore). The USPHS drinking water standards $11 \mathrm{mlt}$ hexavalent chromium to $0.05 \mathrm{ppm}$ but state no limit for the trivalent forms. Limits of $100 \mathrm{ppm}$ for fisheries and $5 \mathrm{ppm}$ for 1rrigation water have been recommended.

Additional work on the analysis of street surface contaminants was carried out by Pitt and Amy [57]. They concluded that industrial and commercial land use areas have the greatest content ( $\mathrm{mg} / \mathrm{kg}$ of heavy metals). They found that the metals associated with street runoff were 100 to 1000 times greater that the sewage metals on a slug load basis ( 1 bs/hour) and from 10 to 100 times on a concentration basis $(\mathrm{mg} / \ell)$. However, the metal content of a street runof was usually not sufficient to cause noticeable reductions in biological treatment efficiency in plants handling 
combined sewage-storm water drains. The solubilities of heavy metals in a simulated receiving water environment (dechlorinated tap water) were low, most being less than $10 \%$ of the available metal. Elemental composition of street surface contaminants determined by mass spectrographic analysis showed the following concentration for chromium and lead:

$\begin{array}{llll} & \text { Residential } & \text { Industrial } & \text { Commercial } \\ \text { Chromium } & 200 \mathrm{mg} / \mathrm{kg} & 500 \mathrm{mg} / \mathrm{kg} & 100 \mathrm{mg} / \mathrm{kg} \\ \text { Lead } & 2000 \mathrm{mg} / \mathrm{kg} & 5000 \mathrm{mg} / \mathrm{kg} & 5000 \mathrm{mg} / \mathrm{kg} \text {. }\end{array}$

In terms of $1 \mathrm{~b} / \mathrm{curb}$ mile $(\mathrm{kg} / \mathrm{curb} \mathrm{km}$ ) the concentrations of chromium and lead were as follows:

Residential Industrial Commercial

Chromium $\quad 0.240(0.067) \quad 1.4(0.394) \quad 0.029(0.008)$

Lead $2.4(0.676) \quad 14(3.94) \quad 1.4(0.394)$

9.0 STREET CONSTRUCTION MATERIALS AND SURFACE CONTAMINANTS AS SOURCES OF CHROMIUM As mentioned previously, street surface contaminants and construction materials contain appreciable amounts of lead and chromium. Amy et al. [58] mentioned special additives used in defcers as causing pollution problems. Chromate and phosphate additives, used as corrosion inhibitors, had been found in high quantities. A study of snow-melt collections conducted in the Minneapolis-St. Paul area showed values of up to $1.7 \mathrm{mg} / \mathrm{l}$ of hexavalent chromium.

Shaheen listed the sources of chromium and lead and also the amounts of $\mu \mathrm{g} / \mathrm{g}$ found on analysis of these "pure" materials. (See Table 21, reference 59). The sources of chromium were as follows: 
1. Wear from metal plating, rocker arms, crankshafts and rings

2. Gasollne - $15 \mu \mathrm{g} \mathrm{Cr} / \mathrm{g}$

3. Asphalt pavement - $357 \mathrm{\mu g} \mathrm{Cr/g}$

4. Concrete - $93 \mu \mathrm{g} \mathrm{Cr} / \mathrm{g}$

5. Rubber - $182 \mu g \mathrm{Cr} / \mathrm{g}$

6. Diesel fuel - $15 \mu \mathrm{g} \mathrm{Cr} / \mathrm{g}$

7. Brake linings - $2200 \mu \mathrm{g} \mathrm{Cr} / \mathrm{g}$

8. Brake fluid - $19 \mu \mathrm{g} \mathrm{Cr} / \mathrm{g}$

9. Cigarettes - $71 \mu \mathrm{g} \mathrm{Cr} / \mathrm{g}$

10. Area soll - $36 \mu \mathrm{gr} / \mathrm{g}$

The sources of lead were as follows:

1. Wear from babbitt metal bearings

2. Gasoline $-663 \mu \mathrm{g} \mathrm{Pb} / \mathrm{g}$

3. Motor oll - $9 \mu \mathrm{g} \mathrm{Pb} / \mathrm{g}$

4. Transmission fluld - $8 \mu \mathrm{g} \mathrm{Pb} / \mathrm{g}$

5. Ant1freeze - $6 \mu g \quad P$

6. Undercoating - $116 \mu \mathrm{g} \mathrm{Pb} / \mathrm{g}$

7. Asphalt pavement - $102 \mu \mathrm{g} \mathrm{Pb/g}$

8. Concrete $-450 \mu \mathrm{g} \mathrm{Pb} / \mathrm{g}$

9. Rubber - $1110 \mu \mathrm{gb} / \mathrm{g}$-- lead oxide is used as a filler in tires

10. Diesel fuel - $12 \mu \mathrm{g} \mathrm{Pb} / \mathrm{g}$

11. Brake Ifnings - $1050 \mu \mathrm{gb} / \mathrm{g}$

12. Brake fluld - $7 \mu \mathrm{g} \mathrm{Pb/g}$

13. Cigarettes - $492 \mu g \mathrm{~Pb} / \mathrm{g}$ 
Traffic paints were not considered in the preparation of these lists. As will be seen from the following calculations, they should not be 1gnored. In our laboratory formulated yellow traffic paint, there are $69 \mathrm{~g}$ of lead chromate in $595 \mathrm{~g}$ of dry paint. The lead chromate is $95.5 \% \mathrm{PbCrO}_{4}$.

$$
\begin{aligned}
& \frac{69 \times 0.955}{595} \times 207.21 / 323 \cdot 22=0.071 \mathrm{~g} \mathrm{~Pb} / \mathrm{g} \text { of dry paint } \\
& \frac{69 \times 0.955}{595} \times 52.01 / 323.22=0.018 \mathrm{~g} \mathrm{Cr} / \mathrm{g} \text { of dry paint }
\end{aligned}
$$

Paints complying with Federal Spec. TT-P-115C had a lead chromate content of 2.52 $1 \mathrm{~b} / \mathrm{gal}(0.30 \mathrm{~kg} / \mathrm{\ell})$ compared to our laboratory formulated paint with $1.36 \mathrm{lb} / \mathrm{gal}$ $(0.16 \mathrm{~kg} / \mathrm{\ell})$. Their $\mathrm{Pb}$ and $\mathrm{Cr}$ concentrations would be $0.071 \times 2.52 / 1.36=0.131$ $\mathrm{g} \mathrm{Pb} / \mathrm{g}$ of dry paint and $0.018 \times 2.52 / 1.36=0.033 \mathrm{~g} \mathrm{Cr} / \mathrm{g}$ of dry paint.

An article by H. V. Warren, an abstract of which appeared in reference [60], discussed the relationship between geology and health. A portion of the abstract is as follows:

"Warren cites Allen-Price's epidemiological studies on cancer in West Devonshire, England, which showed a striking difference in the cancer rate in the different parishes of West Devonshire. He stated that the water supply was the only factor which could account for this difference Millman, whose paper apparently had not been known to Allen-Price, had found an abnormally high content of $\mathrm{Pb}, \mathrm{Hg}, \mathrm{Sn}, \mathrm{Cu}$, and $\mathrm{Zn}$ in trees and soil of this area and high $\mathrm{Pb}$ concentrations in twigs and leaves of trees growing in the proximity of $\mathrm{Pb}-\mathrm{Zn}$ deposits. Howe (1961) reported clearly varying epldemiological patterns for some types of cancer and implicated $\mathrm{Pb}, \mathrm{Zn}$ and polluted water in causing gastric cancer. There was a wide variation in content of $\mathrm{Pb}$ and other metals in rocks and soils." 
10.0 CALCULATION OF POSSIBLE CONTRIBUTION OF YELLOW TRAFFIC STRIPING TO LEAD AND CHROMIUM CONTENT OF ROADWAY PARTICULATES

We have made a calculation of the possible contribution of yellow traffic striping to lead and chromium in roadway particulates. In doing so, the following assumptions have been made: (1) there is complete erosion in 1 year, (2) traffic striping is applied at a rate of $100 \mathrm{ft}^{2} / \mathrm{gal}\left(2.45 \mathrm{~m}^{2} /{ }^{\ell}\right)$ at a wet film thickness of $15 \mathrm{mils}$, and (3) the paint stripe is $4 "(10.1 \mathrm{~cm})$ wide. (4a) The traffic paint has the lead chromate content of Fed. Spec. TT-P-115C or $2.521 \mathrm{~b}$ lead chromate/gal (0.30 $\left.\mathrm{kg} /{ }^{l}\right)$. (4b) The traffic paint has the lead chromate content of our laboratory formulation of $1.36 \mathrm{lb}$ lead chromate/gal $\left(0.16 \mathrm{~kg} /{ }^{l}\right)$. (5) The purity of the lead chromate is $95.5 \% \mathrm{PbCrO}_{4}$.

One gallon $\left(3.785^{\ell}\right)$ of yellow traffic paint would be needed for $300 \mathrm{ft}(0.09 \mathrm{~km})$ of a $4^{\prime \prime}(10.1 \mathrm{~cm})$ wide stripe, $\left(0.333 \times 300^{\prime}=100 \mathrm{ft}^{2}\right)$. It would take $17.6 \mathrm{gal}$ $\left(66.6^{l}\right)$ to paint a strip one mile long $(1.6 \mathrm{~km}),(5280 / 300=17.6 \mathrm{gal} / \mathrm{mi})$.

(a) $17.6 \times 2.52 \times 0.955 \times 207.21 / 323.22=27.151 \mathrm{~b} \mathrm{~Pb}(12.31 \mathrm{~kg})$ eroded in one year or $0.52 \mathrm{lbs} /$ week/curb mile $(0.15 \mathrm{~kg} / \mathrm{wk} / \mathrm{curb} \mathrm{km})$.

$17.6 \times 2.52 \times 0.955 \times 52.01 / 343.22=6.81 \mathrm{lb} \mathrm{Cr}(3.09 \mathrm{~kg})$ eroded $1 \mathrm{n}$ one year or $0.31 \mathrm{lbs} / \mathrm{wk} / \mathrm{curb} \mathrm{mile}(0.037 \mathrm{~kg} / \mathrm{wk}$ curb $\mathrm{km})$.

(b) $17.6 \times 1.34 \times 0.955 \times 207.21 / 232.33=14.431 \mathrm{~b} \mathrm{~Pb}(6.54 \mathrm{~kg})$ eroded 1n one year or $0.28 \mathrm{lbs} / \mathrm{wk} / \mathrm{curb} \mathrm{mile}(0.079 \mathrm{~kg} / \mathrm{wk} / \mathrm{curb} \mathrm{km})$.

$17.6 \times 1.34 \times 0.955 \times 52.01 / 323.22=3.62 \mathrm{lb} \mathrm{Cr}(1.64 \mathrm{~kg})$ eroded $1 \mathrm{n}$ one year or $0.07 \mathrm{lbs} / \mathrm{wk} / \mathrm{curb} \mathrm{mile}(0.020 \mathrm{~kg} / \mathrm{wk} / \mathrm{curb} \mathrm{km})$.

Shaheen demonstrated (see Table 2, reference 61) the significance of traffic-related roadway deposits to urban water pollution. He stated that traffic-related heavy metals constituted the most serious contaminant from the stormwater source when compared with sewage. For example, close to $100 \%$ of the lead entering urban recelvIng water was from traffic-related sources. He said the most serious emission was the traffic-related asbestos deposited on roadways and discharged as an air pollutant. 
Shaheen also commented on the effect of curb height upon the amount of material collected from the roadway. The amount of dust and dirt collected along the roadway smaller than $3.5 \mathrm{~mm}$ particle size increases with curb height up to 15 to 20 inches (38 to $51 \mathrm{~cm}$ ). He sald his data showed that considerable quantities of the smaller size particles became airborne and were carried over the curbs to areas adjacent to the roadways. Lead, zinc and rubber were found to be considerably higher during warm weather while other heavy metals were deposited at a relatively uniform rate throughout the year. This was attributed to greater tire wear at higher ambient temperatures. He further commented that quantitative recovery of particulates from the roadway could be achleved by careful vacuuming of the roadway followed by a separate collection of a water flush of the street surface. The average percent of total lead in the water flush was $4 \%$ (std. dev. $2 \%$ ). The average percent of total chromium in the flush portion was $17 \%$ (std. dev. 15\%. These measurements were taken in the Washington, D.C. area.

\subsection{CONCLUSIONS}

Based upon a survey of the literature, the following conclusions may be made:

1. Reports from Germany, Japan, England, France, Sweden, Norway, and Italy as well as the U.S.A. emphasize the high incidence of lung cancer and other respiratory diseases among workers involved in the manufacture of chromates.

2. According to the National Academy of Science report on chromium, the carcinogens present in the chromate manufacturing process have not been identified. 
3. Hexavalent chromium is toxic for all body cells. The USPHS limits 1 ts concentration in water to $0.05 \mathrm{pm}$. The NIOSH limits concentration in working areas to $1 \mathrm{\mu g} \mathrm{Cr}^{+6} / \mathrm{m}^{3}$.

4. In animal studies, calcium chromate was found to produce cancer in rats.

5. No harmful effects from chromium metal in the ambient air are known. Chromium is an essential tract element.

6. The USPHS drinking water standards limit lead to $0.05 \mathrm{ppm}$.

7. Water pollution from storm water runoff is considerably higher than from sanitary sewage. Traffic-related heavy metals, including lead and chromium, constitute the most serious contaminant for the storm water sources.

8. The fine solids fraction of street surface contaminants accounts for a great portion of the pollution potential.

It was noted that the literature search showed several gaps in information on lead and chromium in environment. Among these were:

- The exact sources of chromium in air pollution are not known, although several possible sources were cited.

- The contribution of yellow traffic paint striping to the lead chromium content of roadway particulates, stormwater runoff, or of areas adjacent to roadways is not known.

- No work has been reported on the measurement of lead chromate in the amblent air during the application of leaded traffic paint. (This 
is surprising in view of the high incidence of lung cancer among workers in chromate pigment plants and of lead poisoning among spray painters employing lead paints in auto factories).

These gaps may suggest areas for future study. 


\subsection{REFERENCES}

1. Chemical Marketing Reporter, July 7, 1975.

2. Nebergall, William H. and Schmidt, Frederic C., "College Chemistry," pp. 479481, D.C. Health \& Co., Boston, 1957.

3. Udy, Marvin J., "Chromium" Vol. 1, pp. 267-270, Reinhold Publishing Corp., New York, 1956.

4. Wormald, George, "Treatise on Coatings," Vol. 3, P1gments, Part I, pp. 3169, edited by Raymond R. Myers and J. S. Long.

5. Enterline, Philip E., "Respiratory Cancer Among Chromate Workers," Journal of Occupational Medicine 16, No. 8, pp. 523-6, 1974.

6. Machle, W., and Gregorious, F., "Cancer of the Respiratory System in the United States Chromate-Producing Industry," Public Health Report 63 , No. 35 , pp. 1114-1127, Reprint No. 2882, August 1948.

7. Federal Security Agency, "Health of Workers in Chromate Producing Industry, A Study." U.S. Public Health Service Publication No. 192, Washington, D.C., U.S. Government Printing office, 1953.

8. Sullivan, R. M., et al., Litton Industries, Inc., "Alr Pollution Aspects of Chromium and Its Compounds," pp. 9-14, PB 188 075, National Technical Information Service.

9. Baetjer, A. M., "Relation of Chromium to Health," Chromium, Vol. 1, Chapter 4, ed. M. J. Udy, American Chemical Society Monograph 132, New York, Reinhold, 1956.

10. Utidjian, Michael H., "Criterion for a Recommended Standard -- Occupational Exposure to Chromic Acid," Journal of Occuptional Medicine 15, No 12, pp. $983-5,1973$. 
11. Bidstrup, P. L. and Case, R. A. M., "Carcinoma of the Lung in Workmen in the Bichromates-Producing Industry in Great Britian," British Journal of Industrial Medicine 13, Pp. 260-264, 1956.

12. Oettel, Von H. Thiess, A. M. and Uh1, C., "Contribution to the Problem of Occupational Lung Cancer-Chromate Induced Lung Cancer," Zentrallblatt fur Arbeitsmedizin and Arbeitsschutz, 18, No. 10, pp. 291-303, 1968.

13. Capodaglio, E., Pezzagno, G. and Ghittori, S., "Funcitonal State of the Respiratory System and Work Environment Pollution. 1. A Respiratory Function and Environmental Pollution Survey," Lavoro Umano, 26, No. 4, pp. 97-124, 1974.

14. Pica, A. (University Florence, Italy), "Hygienic Sanitary Studies in Two Ceramic Dye Factories," Rassegna di Medicina Industriale e di Igiene de Lavoro, $\underline{32}$, pp. 465-479, 1963.

15. Hartogensis, F., and Zielhuis, R. L. (Research Institute of Public Health Engineering, The Hague; Netherlands Institute for Preventive Medicine, Leiden), "Health Standards for Lead Chromate Dust." Annals of Occupational Hygiene $\underline{5}$, Pp. 27-36, 1962

16. Campbe11, Irene R. and Mergard, Estelle, G., "Biological Aspects of Lead: An Annotated Bibliography," Part 1, p. 502, Environmental Protection Agency, May 1972.

17. Campbel1, Irene R. and Mergard, Estelle, G., "Biologicàl Aspects of Lead: An Annotated Bibliography," Part 1, p. 464, Environmental Protection Agency, May 1972.

18. Onsake, Abe, Homa, Yozawa, Kishi, and Murao, School of Medicine, Hokkaido University "High Incidence of Lung Cancer in Chromate Workers," Journal of Japanese Society of Internal Medicine, 10, pp. 1198-1203, 1974. 
19. Chasaki, Y., Abe, S., Kimura, K., Tsumeta, Y., Mikami, H., and Murao, M. "Lung Cancer in Japanese Chromate Workers", Thorax 33, 372-374, 1978.

20. Fraumeni, J.F., Jr., "Respiratory Carcinogenesis. An Epidemiologic Appraisal." J. National Center Institute 55, No. 5, pp. 1039-46, Nov. 1975.

21. Langard, Sverre and Norseth, Tor, "A Cohort Study of Bronchial Carcinomas in Workers Producing Chromate Pigments," British Journal of Industrial Medicine, 32, pp. 62-65, Feb. 1975 .

22. Davies, J. M. "Lung Cancer Mortality of Workers in Chromate Pigment Manufacture: An Epidemiological Survey", J. 011 Col. Chem. Assoc. 62, pp 157-163, 1979.

23. Committee on Blologic Effects of Atmospheric Pollutants, Division of Medical Sciences, National Research Council, "Medical and Blologic Effects of Environmental Pollutants-Chromium," pp. 54-59, National Academy of Sciences, 1974.

24. Diechmann, William B. and Gerarde, Horace, W., "Toxicology of Drugs and Chemicals," p. 1976, Academic Press 1969.

25. Rausher, F. J., "Eventual Control and Prevention of Leukemia and Related Neoplasma," Unifying Concepts of Leukemia, Bibliotheca Haematologica, No. 39, PP. 1237, ed. by R. M. Dutcher and L. Chieco-Bianchi (Karger, Basel 1973).

26. Graway, Gerald W., "The Criteria Document for Chromic Acid," Journal of Occupational Medicine, 15, No. 12, p. $986,1973$.

27. Neronski1, 0. G. (Institute of Medicine, Minsk, USSR): "The Toxicity of Paint Aerosols Containing Lead," Gigiena Truda 1 Professional 'nye Zabolevaniya $\underline{8}$, pp. $52-4,1964$.

28. Ankerst. H. and Weimer, G., "Hazards in Work with Toxic Raw Materials for Enamels and Auxiliary Chemicals," Glas-Email-Keramo-Technik 14, No. 4, pp. $124-6,1963$ 
29. Zielhuis, R. L. (Paint and Health. I, II, III.) Verfkroniek 30, pp. 178-80, $196-7 ; 207-11,1957$.

30. Berghout, C. R. (Army Chemical Center, MD), "Spray Painting Without Compressed Air," Archieves of Environmental Health 1 , pp. 534-9, 1960.

31. Annonymous: "Cleveland Paint Factories Install Ventilation to Protect Workers from Lead," Occupational Health 12, p. 44, March 1952.

32. Campbe11, Irene R. and Mergard, Estelle, G., "Biological Aspects of Lead: An Annotated Bbliography" Parts I and II, Abstracts Nos. 2771, 2498, 3146, 3165, and 3091, Environmental Protection Agency, May 1972.

33. U. S. Department of Health, Education and Welfare, National Institute for Occupational Safety and Health, Cincinnati, Ohio "Health Hazard Evaluation Determination Report No. 73-47-172.

34. U. S. Department of Health, Education and Welfare, "National Institute for Occupational Safety and Health, Cincinnati, Ohio 45202. Health Hazard Evaluation Determination Report No. 73-99-108.

35. Wallgren, Per-Ake, "The Effect of Hazardous Materials on the Human Body," Farg Och Lack $\underline{3}$, pp. 47-51, 1972.

36. Committee on Biologic Effects of Atmospheric Pollutants, Division of Medical Sciences, National Research Council, "Medical and Blologic Effects of Environmental Pollutants-Chromium," pp. 23-24 and 73, National Academy of Sciences, 1974.

37. Hansen, J. C., "The Toxicology of Some Heavy Metals," Ugeskrift fur Laeger 136, No. 16, pp. 853-8, 1974 .

38. Feldman, F. J., "The State of Chromium In Biological Materials," Federal Proceedings 27, p. 482, 1968 (abstract). 
39. Kuschner, M. and Laskin, S., "Experimental Models in Environmental Carcinogenesis," American Journal of Pathology, 64, No. 1, pp. 183-6, July 1971.

40. Laskin, S., Kuschner, M. and Drew, R. T., "Studies in Pulmonary Carcinogenesis," pp. 321-350. In M. G. Hanna, Jr., P. Nettesheim and J. R. Gilbert, Eds. Inhalation Carcinogenesis. AEC Symposium Series 18, Oak Ridge, Tenn., United States Atomic Energy Commission Division of Technical Information, 1970.

41. Roe, F. J. C. and Carter, R., "Chromium Carcinogenesis. Calcium Carbonate as a Potent Carcinogen for the Subcutaneous Tissues of the Rat" British Journal of Cancer 23 , pp. 172-6, 1969.

42. Netteshe1m, P. M., Hanna, M. G., Jr., Doherty, D. G., Newell, R. F., and Hellman, A., "Effects of Chronic Exposure to Artifical Smog and Chromium Oxide dust on the Indicence of Lung Tumors in Mice," pp. 305-320. In M. G. Hanna, Jr., P. Nettesheim and J. R. Gilbert, Eds. Inhalation Carinogenesis, AEC Symposium Serles 18 Oak Ridge, Tenn., U.S. Atomic Energy Commission, Division of Technical Information, 1970.

43. M1dwest Research Institute, "Lead Paint Ingestion Study," National Paint and Coatings Association, Inc., Washington, D.C., 1974.

44. Furst A., Schlauder, M., Sasmore, D. P. "Tumorigenic Activity of Lead Chromate", Cancer Research 36 (5), pp. 1779-1783.

45. Christofano, E. E., Kennedy, G. L., Gordon, D. E. Keplinger, M. L. \& Calandra, J. C., Hercules, Inc., Wilmington, Delaware; and Industrial Bio-Test Laboratories, Inc., Northbrook, Illinols "Toxicity of Lead Chromate Pigments and T1ssue Residues Following 90 days feeding to Beagle Dogs", Toxicology and Applied "Pharmocology, 37, No. 1, p 161, 1976.

46. Magee, P. N., "Carcinogens in the Environment," Proceedings of the Royal Society of Med1c1ne," 67, No. 8, pp. 741-3, 1974. 
47. Woolrich, Paul F., "Occurrence of Trace Metals in the Environment - An Overview," American Industrial Hygiene Association Journal 34 , No. 5, pp. $217-226,1973$.

48. Shakman, Robert A., "Nutritional Influences on the Toxicity of Environmental Pollutants," Archives of Environmental Health, 28, p. 197, 1974.

49. Dreisbach, Robert H., "Handbook of Poisoning: Diagnosis and Treatment," 8th ed., p. 201, Lange Medical Publications, 1974.

50. Litton Industries, Inc., "Air Pollution Aspects of Chromium and Its Compounds," Pp. 1, 19-25, PB 188 075, National Technical Information Service.

51. Ibid, p. 36 .

52. Committee on Biologic Effects of Atmospheric Pollutants, Division of Medical Sciences, National Research Council, "Medical and Biologic Effects of Environmental Pollutants-Chromium," pp. 107-108, National Academy of Sciences, 1974.

53. Linton, R. W.; LOH, A; Natusch, D. F. S.; Evans, C. A. Jr; Williams, P. "Surface Predominance of Trace Elements in Airborne Particles", Science 191 , 852-4 1976 .

54. Committee on Biologic Effects of Atmospheric Pollutants, Division of Medical Sciences, National Research Council, "Medical and Biologic Effects of Environmental Pollutants-Chromium", pp. 90-91, National Academy of Sciences, 1974.

55. NIOSH Criteria for Recomended Standard. 1. Occupational Exposure to Cr (VI), HEW Publication No. (NIOSH) 76-129.

56. Sarter, James D. and Boyd, Gail B, "Water Pollution Aspects of Street Surface Contaminants," EPA-R2-72-081, pp. 2-4, 27-31, 50, 68, 74-76, 136-7. Nov. 1972. 
57. Pitt, Robert E. and Amy, Gary, "Toxic Materials Analysis of Street Surface Contaminants," EPA-R2-73-283, pp. 1, 12, 17, August 1973.

58. Amy, Gary; Pitt, Robert; Singh, Rameshawar; Bradford, Westly; and La-Graff, Michae1, "Water Quality Management Planning for Urban Runoff," EPA-440/9-75-004, Sect. 3, p. 2, December 1974.

59. Shaheen, Donald G., "Contributions of Urban Roadway Usage to Water Pollution," EPA 600/2-75-004, p. 72, Apri1 1975 .

60. Campbell, Irene R. and Mergard, Estelle G., "Biological Aspects of Lead: An Annotated Bibliography" Part 1, p. 478, Environmental Protection Agency, May 1972 .

61. Shaheen, Donald G., "Contributions of Urban Roadway Usage to Water Pollution," EPA 600/2-75-004, p. 5, Apri1 1975. 


\begin{tabular}{|c|c|c|c|}
\hline $\begin{array}{l}\text { U.S. DEPT. OF COMM. } \\
\text { BIBLIOGRAPHIC DATA } \\
\text { SHEET }\end{array}$ & $\begin{array}{l}\text { 1. PUBLICATION OR REPORT NO. } \\
\qquad 80-1974\end{array}$ & & \\
\hline \multicolumn{3}{|c|}{$\begin{array}{l}\text { 4. TITLE AND SUBTITLE } \\
\text { Lead Chromate Pigments - A Literature Survey on } \\
\text { Environmental and Toxic Effects }\end{array}$} & 5. Putlication Date \\
\hline \multicolumn{3}{|c|}{$\begin{array}{l}\text { 7. AUTHOR(S) } \\
\text { M. A. Post and P. G. Campbell }\end{array}$} & 8. Performing Organ, Report No. \\
\hline \multirow{2}{*}{\multicolumn{3}{|c|}{$\begin{array}{l}\text { 9. PERFORMING ORGANIZATION NAME AND ADDR } \\
\text { NATIONAL BUREAU OF STANDARDS } \\
\text { DEPARTMENT OF COMMERCE } \\
\text { WASHINGTON, DC } 20234\end{array}$}} & $\begin{array}{l}\text { 10. Rroject/Task/Work Únit No. } \\
4615455\end{array}$ \\
\hline & & & $\begin{array}{l}\text { 11. Contiact/Grant No. } \\
\text { FHWA No. P.O. 5-4-0188 }\end{array}$ \\
\hline \multicolumn{3}{|c|}{$\begin{array}{l}\text { 12. SPONSORING ORGANIZATION NAME AND COMPLETE ADDRESS (Street, City, State, ZIP) } \\
\text { Office of Research and Development } \\
\text { Federal Highway Administration } \\
\text { U.S. Department of Transportation } \\
\text { Washington, D.C. } 20590\end{array}$} & 13. Type of Repoit \& Period Covered \\
\hline \multicolumn{4}{|c|}{$\begin{array}{l}\text { 15. SUPPLEMENTARY NOTES } \\
\square \text { Document describes a computer program; SF-185, FIPS Software Summary, is attached. }\end{array}$} \\
\hline \multicolumn{4}{|c|}{$\begin{array}{l}\text { In connection with an evaluation of the performance of possible alternative yellow } \\
\text { pigments, a literature search was made on the toxicity and environmental effects of } \\
\text { lead chromate pigments. The literature reveals that workers in chromate plants in } \\
\text { the U.S., Europe and Japan have had a high incidence of lung cancer as well as other } \\
\text { respiratory ailments. Further, reports on the biologic interactions of chromium } \\
\text { show that chromium in its hexavalent state (chromate, dichromate) penetrates body } \\
\text { membranes such as skin and the walls of red blood cells and is subsequently reduced } \\
\text { to the trivalent state and complexed with organic molecules. While the carcinogen } \\
\text { in the chromate manufacturing process has not been identified, animal experiments } \\
\text { have shown that calcium chromate can produce cancer in rats. Information is } \\
\text { presented on sources of chromium in air and water pollution. Also, the pollution } \\
\text { aspects of lead and chromium in storm water runoff and as street contaminants are } \\
\text { reviewed. }\end{array}$} \\
\hline
\end{tabular}

17. KEY WORDS (six to twelve entries; alphabetical order; capitalize only the first letter of the first key word unless a proper name; separated by semicolons)

Air pollution; chromate ore; environmental effects; lead chromate pogments; storm water runoff; toxicity; water pollution.

U.S. DEPT. OF COMM.

GRAPHIC DATA

SHEET

Lead Chromate Pigments - A Literature Survey on

Environmental and Toxic Effects

DEPARTMENT OF COMMERCE

WASHINGTON, DC 20234

Office of Research and Development

U.S. Department of Transportation

Washington, D.C. 20590
Project/Task/Work Únit No.

1. Contiact/Grant No.

FHWA No. P.O. 5-4-0188

13. Type of Report \& Period Covered 


$\therefore \quad \cdots$ 